\title{
IDENTIFIKASI BAKTERI RESISTEN MERKURI PADA URINE, FESES DAN KALKULUS GIGI PADA INDIVIDU DI KECAMATAN MALALAYANG, MANADO, SULAWESI UTARA
}

\author{
${ }^{1}$ Sarah Mariana Pattuju \\ ${ }^{2}$ Fatimawali \\ ${ }^{2}$ Aaltje Manampiring \\ ${ }^{1}$ Kandidat Skripsi Fakultas Kedokteran Universitas Sam Ratulangi Manado \\ ${ }^{2}$ Bagian Kimia Fakultas Kedokteran Universitas Sam Ratulangi Manado \\ Email: mayapattuju@ymail.com
}

\begin{abstract}
Consumption of shells, fishes and some sea mammals is one of the main track in which people get contaminated by mercury. Mercury is neurotoxin and is very harmful for human body. Mercury accumulation in human body resulted in bacteria adapting and its being resistance to mercury. Objective: To detect the existence of bacteria that can live in the environmental condition contaminated by mercury and to identify mercury resistance bacteria on urine, feces and dental calculus of individual in district Malalayang, Manado, North Sulawesi. Method: This research employs explorative descriptive research design. The sample of the study is the mercury resistance bacteria on urine, feces, and dental calculus in district Malalayang, Manado, North Sulawesi. The study is begun conducted in October and end in December 2013. The study is begun done by isolating mercury resistance bacteria on Broth Nutrient containing $\mathrm{HgCl}_{2}$ and Phenylmercury, continued by morphology testing, physiology testing and biochemistry testing in Biotechnology Laboratory of MIPA faculty of Sam Ratulangi University. Result: There are mercury resistance bacteria on urine, feces and dental calculus taken from individual in district Malalayang. There are 3 genus of Bacteria founded, which are E. Coli, Staphylococcus and Bacillus sp. In this study, the highest level of bacteria resistance on mercury conducted on $\mathrm{HgCl}_{2}$ concentration of $10 \mathrm{ppm}, 20 \mathrm{ppm}$ and $40 \mathrm{ppm}$ is on concentration of $40 \mathrm{ppm}$. On Phenylmercury with concentration of $5 \mathrm{ppm}, 10 \mathrm{ppm}$ and $20 \mathrm{ppm}$ is on concentration of $20 \mathrm{ppm}$.
\end{abstract}

Key Words: Mercury, bacteria, urine, feces, dental calculus.

\begin{abstract}
Abstrak: Konsumsi kerang, ikan dan beberapa mamalia laut merupakan salah satu jalur utama masyarakat terpapar merkuri. Merkuri bersifat neurotoksin dan sangat berbahaya bagi tubuh. Akumulasi merkuri dalam tubuh mengakibatkan bakteri beradaptasi dan kemudian menjadi resisten terhadap merkuri.Tujuan Penelitian: Untuk mengetahui adanya bakteri yang dapat hidup pada kondisi lingkungan yang telah tercemar merkuri dan mengidentifikasi bakteri resisten merkuri pada urine, feses dan kalkulus gigi pada individu di Kecamatan Malalayang, Manado, Sulawesi Utara. Metode Penelitian: Penelitian ini menggunakan desain penelitian deskriptif eksploratif. Sampel pada penelitian ini adalah bakteri resisten merkuri pada urine, feses dan kalkulus gigi yang diambil dari seorang penduduk di Kecamatan Malalayang, Manado, Sulawesi Utara. Penelitian di laksanakan mulai bulan Oktober sampai bulan Desember 2013. Penelitian dilakukan mulai dari isolasi bakteri resisten merkuri pada Nutrient Broth yang mengandung $\mathrm{HgCl}_{2}$ dan Fenil Merkuri, dilanjutkan uji morfologi, uji fisiologi dan uji biokimia di Laboratorium Bioteknologi Fakultas MIPA Universitas Sam Ratulangi. Hasil: Terdapat bakteri resisten merkuri pada urine, feses dan karang gigi yang diambil dari individu di Kecamatan Malalayang. Ada 3 genus bakteri yang ditemukan yaitu E. Coli, Staphylococcus dan Bacillus sp. Tingkat resistensi bakteri terhadap merkuri yang tertinggi pada peneltian ini yang dilakukan pada konsentrasi $\mathrm{HgCl}_{2} 10$ ppm, 20 ppm dan 40 ppm yaitu pada konsentrasi 40 ppm. Pada Fenil Merkuri dengan konsentrasi 5 ppm, 10 ppm dan 20 ppm yaitu pada konsentrasi 20 ppm.
\end{abstract}

Kata kunci: Merkuri, bakteri, urine, feses, kalkulus gigi. 
Indonesia adalah negara kepulauan terbesar di dunia. Sekitar tiga perempat wilayahnya berupa laut seluas 5,8 juta $\mathrm{km}^{2}$ yang mempersatukan $17.508 \mathrm{~km}$ garis pantai. ${ }^{1}$ Sebagai negara yang memiliki struktur geografis yang dikelilingi oleh laut, maka laut menjadi tumpuan untuk memenuhi kebutuhan hidup terutama masyarakat di pesisir pantai. Pada mulanya hasil buangan sampah dan sisa-sisa industri yang berasal dari aktivitas manusia di daratan dapat ditampung di laut tanpa menimbulkan bahaya apapun. Namun dengan meningkatnya pertumbuhan penduduk dunia maka meningkat pula lingkungan industri yang mengakibatkan makin banyak bahan-bahan beracun yang dibuang ke laut.

Sebagian besar sumber pencemaran laut berasal dari daratan, baik tertiup angin, terhanyut maupun melalui tumpahan. Salah satu bahan pencemarnya yaitu limbah kimia yang bersifat toxic (racun) dan sangat berbahaya. Merkuri atau air raksa merupakan limbah kimia yang mempunyai kepadatan yang relatif tinggi dan bersifat racun atau beracun pada konsentrasi rendah.

Merkuri bersifat neurotoksin dan masuk ke ekosistem akuatik melalui deposisi atmosferik maupun bersumber dari eksternalisasi limbah industri. ${ }^{2}$ Sumber pencemaran merkuri dapat berasal dari proses geologi dan biologi, tapi tidak sebanding dengan pencemaran merkuri yang disebabkan oleh aktivitas manusia seperti: pembakaran batu bara, jenis-jenis produk minyak bumi, penggunaan fungisida, katalisator merkuri dan penambangan emas yang menggunakan merkuri sebagai bahan pengekstraksi emas. ${ }^{3}$ Merkuri total dalam atmosfer berkembang tiga kali lipat akibat kegiatan antropogenik. ${ }^{4}$

Pada manusia paparan merkuri dengan dosis tinggi dapat berakibat fatal, namun dengan dosis yang relatif rendah sekalipun, merkuri dan senyawanya dapat memberi pengaruh yang serius. ${ }^{5}$ Merkuri dikenal bersifat neurotoksin yang dapat menyebabkan kerusakan pada ginjal dan merusak sistem tubuh di antaranya sistem saraf, kardiovaskular, pernapasan, gastrointestinal, hati, imun dan sistem reproduksi. ${ }^{6,7}$ Environmental Protection Agency dan
National Academy of Science menyatakan bahwa wanita Amerika yang terpapar merkuri dapat melahirkan anak dengan penyakit saraf. ${ }^{8}$ Merkuri yang masuk ke dalam tubuh didistribusi melalui ginjal dan otak dan siap ditransfer ke janin melalui plasenta. Kemudian di eliminasi melalui urin, feses, ekspirasi dan air susu ibu. ${ }^{9}$

Konsumsi kerang, ikan dan beberapa mamalia laut merupakan salah satu jalur utama masyarakat terpapar merkuri. ${ }^{10}$ Kecamatan Malalayang terletak di pesisir pantai. Dengan demikian masyarakat memiliki resiko tinggi terpapar air yang tercemar dan juga terpapar bahan kimia khususnya merkuri melalui ikan dan hewan laut lainnya yang dikonsumsi selama bertahun-tahun. Namun beberapa mikroorganisme di dalam usus juga secara perlahan akan beradaptasi untuk bertahan hidup pada lingkungan yang mengandung merkuri pada usus manusia. Hal ini diperkuat dengan hasil penelitian oleh Liebert pada tahun 2001, yang menyatakan terdapat gen resisten merkuri pada feses dan primata lainnya. Oleh karena itu, penulis tertarik untuk meneliti bakteri resisten merkuri pada feses, urin dan kalkulus gigi pada individu di Kecamatan Malalayang, Manado, Sulawesi Utara.

\section{METODE PENELITIAN}

Jenis penelitian ini adalah deskriptif eksploratif. Penelitian ini dilaksanakan mulai Oktober-Desember 2013, dilakukan di Kecamatan Malalayang, Manado, Sulawesi Utara. Analisa sampel dilakukan di Laboratorium Bioteknologi Fakultas MIPA Universitas Sam Ratulangi. Populasi yaitu berbagai jenis bakteri yang ada dalam feses, urin dan kalkulus gigi pada individu di Kecamatan Malalayang, Manado, Sulawesi Utara. Sampel dalam penelitian ini adalah bakteri resisten merkuri pada urine, feses dan kalkulus gigi yang diambil dari seorang penduduk di Kecamatan Malalayang, Manado, Sulawesi Utara. Kriteria Inklusi: (1) Berdomisili lebih dari 30 tahun di Kecamatan Malalayang, Manado, Sulawesi Utara. (2) Tidak pernah berpindah-pindah 
tempat tinggal. (3) Bekerja sebagai nelayan. (4) Bersedia menjadi subjek penelitian. Kriteria Eksklusi: umur dibawah 30 tahun dan menolak untuk menjadi subjek penelitian. Variabel penelitian adalah bakteri resisten merkuri. Alat yang digunakan di lapangan: Handscoen, botol atau tabung steril bertutup ulir, aquades/air suling, sabun medis, masker, kaca mulut, senter, scaler manual. Alat yang digunakan di Laboratorium: ASS (Atomic Absorption Spectonometry), $\mathrm{pH}$ meter, object glass, Erlenmeyes $100 \mathrm{ml}$, lampu spiritus, pemanas listrik dan pengatur suhu, pipet, tabung reaksi, gelas ukur, jarum ose, gelas piala, cawan petri. Bahan yang digunakan yaitu sampel (Urine, feses, kalkulus gigi), media agar, buffer saline, media dan reagen untuk uji morfologi, fisiologi dan biokimia. Pengambilan sampel diawali dengan sampel urine, feses dan kalkulus gigi diambil secukupnya dan di masukkan ke dalam tabung yang telah disterilisasi terlebih dahulu. Sampel yang telah diambil kemudian dibawa ke Laboratorium Bioteknologi Fakultas MIPA Universitas Sam Ratulangi untuk dikultur dan diuji resistensinya terhadap merkuri serta diidentifikasi berdasarkan morfologi dan sifat biokimianya. Isolasi bakteri resisten merkuri sampel diambil sebanyak $1 \mathrm{ml}$ larutan urine, feses dan kalkulus gigi dan ditumbuhkan pada media Nutrient Broth yang telah mengandung $\mathrm{HgCl}_{2}$ dengan konsentrasi 10 ppm, 20 ppm, 40 ppm dan Fenil yang mengandung konsentrasi 5 ppm, 10 ppm dan 20 ppm. Kemudian diinkubasi selama 24 jam pada suhu $37^{\circ} \mathrm{C}$. Lalu ditumbuhkan pada medium padat di cawan petri untuk mendapatkan koloni bakteri resisten merkuri. Setelah itu diinkubasi lagi selama 24 jam pada suhu $37^{\circ} \mathrm{C}$. Koloni yang tumbuh dalam medium padat diambil bakteri tunggal dan dipindahkan lalu digoreskan pada media padat lainnya. Bakteri ini lalu diinkubasi dan diperiksa 24 jam kemudian, bakteri dipindahkan ke agar miring untuk mendapatkan bakteri murni sekaligus sebagai isolat bakteri resisten merkuri. Setelah itu mengidentifikasikan bakteri dengan cara uji morfologi, fisiologi dan biokimia. Uji morfologi dilakukan dengan pewarnaan Gram, dengan cara: (1) Buat preparat ulas (smear) yang telah difiksasi; (2) Teteskan kristal vilet sebagai pewarna utama pada kedua preparat, usahakan semua ulasan terwarnai dan tunggu selama 1 menit; (3) Cuci dengan akuades mengalir; (4) Teteskan mordant (lugol, s iodine) lalu tunggu 1 menit; (5) Cuci dengan akuades mengalir; (6) Beri larutan pemucat (ethanol 96\%/aseton) setetes demi setetes hingga etanol yang jatuh berwarna jernih. Jangan sampai terlalu banyak (overdecolorize);(7) Cuci dengan akuades mengalir; (8) Teteskan counterstain (safranin) dan tunggu selama 45 detik; (9) Cuci dengan akuades mengalir; (10) Keringkan preparat dengan kertas tissue yang ditempelkan di sisi ulasan (jangan sampai merusak ulasan) lalu biarkan mengering di udara. Uji fisiologi dilakukan dengan uji motility. Prosedur uji motilitas yaitu : siapkan media Motility Test Medium dan masukan ke dalam tabungan yang telah diberi label sesuai dengan kode biakan bakteri yang akan digunakan sebanyak $5 \mathrm{ml}$. Kemudian media disterilkan pada suhu $121^{\circ} \mathrm{C}$ selama 15 menit, lalu dinginkan. Setelah media dingin, kultur sediaan diinokulasi ke dalam media dengan cara menusukan jarum ose sampai ke dasar media, kemudian diinkubasi pada suhu $37^{\circ} \mathrm{C}$ selama 24 - 48 jam. Hasil pengamatan kemudian dicatat. ${ }^{11}$ Uji Biokimia meliputi uji Indol, uji $\mathrm{H}_{2} \mathrm{~S}$ dan Fermentasi Karbohidrat, uji Katalase, uji Sitrat, Uji Lysine Dekarboksilase. Uji Indol menggunakan reagen Kovac's dengan cara :(1) Beri label pada tabung medium perbenihan peptone dengan nama; (2) Gunakan teknik aseptik, lalu inokulasi bakteri sebanyak satu ose pada masing - masing tabung biakan; (3) Inokulasi pada suhu $37^{\circ} \mathrm{C}$ selama 24 jam. Hasil uji positif ditandai dengan terbentuknya warna merah. ${ }^{12} \mathrm{Uji} \mathrm{H}_{2} \mathrm{~S}$ dan Fermentasi Karbohidrat prosedur kerjanya sebagai berikut: (1) Dibuat media Triple Sugar Iron Agar (TSIA) seperti pada uji $\mathrm{H}_{2} \mathrm{~S}$ dimasukkan kedalam tabung Hach sebanyak $6 \mathrm{ml}$; (2) Media di sterilkan pada suhu $121^{\circ} \mathrm{C}$ selama 15 menit. Didinginkan pada 
posisi miring kemudian secara aseptik setiap isolat bakteri di inokulasi dengan jarum inokulasi lurus dengan cara di tusuk pada bagian tengah sampai kedalaman $3 / 4$ bagian dari permukaan media dan setelah itu digores pada bagian (slant) dari media; (3) Diinkubasi selama 24 jam pada suhu $37^{\circ} \mathrm{C}$. Uji Katalase dengan cara: (1) Koloni bakteri diambil satu ose secara aseptis dan diinokulasikan pada Object glass; (2) Dengan menggunakan pipet tetes, 3\% H2O2 diteteskan pada Object glass secukupnya; (3) Amati adanya gelembung untuk hasil positif dan tidak ada gelembung untuk hasil negatif (hati-hati membedakan antara gelembung yang muncul dari sel dengan kumpulan sel yang mengambang akibat ditambahi reagen).Uji Sitrat dengan cara: (1) Disiapkan media Simmons's Citrate Agar; (2) Dengan menggunakan teknik steril setiap bakteri di inokulasi kedalam tabung yang berisi media yang telah di beri label dengan cara ditusuk dan setelah itu digores; (3) Inkubasi selama 24-48 jam pada suhu $37^{0} \mathrm{C}$; (4) Uji bersifat positif bila terjadi perubahan warna pada media dari hijau tua menjadi warna biru. ${ }^{13}$ Uji Lysine Dekarboksilasedilakukan dengan cara: (1) Disiapkan media Lysin Iron Agar, lalu sebanyak $6 \mathrm{ml}$ media dimasukkan kedalam tabung Hach; (2) Media disterilkan dengan autoklaf pada suhu $121^{\circ} \mathrm{C}$ selama 15 menit dengan tekanan 15 psi; (3) Setelah disterilkan, media dibuat menjadi agar miring; (4)Diinokulasikan bakteri dengan cara ditusukkan dan digoreskan pada media Lysin Iron Agar miring; (5) Diinkubasi pada suhu $37^{0} \mathrm{C}$ selama 24-48 jam.

\section{HASIL PENELITIAN}

\section{Hasil isolasi bakteri resisten merkuri}

Dari 18 isolat yang di uji didapatkan hasil positif dengan koloni bakteri yang terbentuk berwarna putih keruh. Maka diambil 6 isolat dengan konsentrasi merkuri paling tinggi dan digunakan untuk identifikasi bakteri pada uji selanjutnya. Kode isolat untuk media yang berisi $\mathrm{HgCl}_{2}$ yaitu S.U 40, S.F 40 dan S.K 40, sedangkan kode isolat untuk Fenil Merkuri yaitu S.U
20, S.F 20 dan S.K 20. Isolat yang sudah dipilih kemudian ditumbuhkan pada medium padat di cawan petri selama 24 jam pada suhu $37^{\circ} \mathrm{C}$. Dari hasil pengamatan bentuk koloni, permukaan dan warnanya maka didapatkan 7 isolat.

Tabel 1. Hasil pengamatan bentuk koloni, permukaan dan warna $\mathrm{HgCl}_{2}$

\begin{tabular}{cccc}
\hline \multirow{2}{*}{$\begin{array}{c}\text { Kode } \\
\text { Isolat }\end{array}$} & $\begin{array}{c}\text { Bentuk } \\
\text { Koloni }\end{array}$ & $\begin{array}{c}\text { Permukaan } \\
\text { Koloni }\end{array}$ & $\begin{array}{c}\text { Warna } \\
\text { Koloni }\end{array}$ \\
\hline S.U 40 & Bulat & Halus & Putih \\
S.F 40 & Bulat & Halus & Putih \\
S.F 40 & Bulat & Halus & Putih \\
S.K 40 & Bulat & Halus & Kuning \\
\hline
\end{tabular}

Tabel 2. Hasil pengamatan bentuk koloni, permukaan dan warna fenil

\begin{tabular}{cccc}
\hline \multirow{2}{*}{$\begin{array}{c}\text { Kode } \\
\text { Isolat }\end{array}$} & \multicolumn{3}{c}{ Fenil Merkuri } \\
\cline { 2 - 4 } & $\begin{array}{c}\text { Bentuk } \\
\text { Koloni }\end{array}$ & $\begin{array}{c}\text { Permukaan } \\
\text { Koloni }\end{array}$ & $\begin{array}{c}\text { Warna } \\
\text { Koloni }\end{array}$ \\
\hline S.U 20 & Bulat & Halus & Kuning \\
S.F 20 & Bulat & Halus & Putih \\
S.K 20 & Bulat & Halus & Kuning \\
\hline
\end{tabular}

Koloni kemudian diambil dan dipindahkan pada media gores dan terakhir pada agar miring. Maka didapatkan bakteri murni sekaligus sebagai isolat bakteri resisten merkuri dengan kode S.U 40 B.K, S.F 40 B.P, S.F 40 BP, S.K 40 B.P, S.U 20 B.K, S.F 20 B.P, S.K 20 B.K.

\section{IDENTIFIKASI BAKTERI}

\section{Uji morfologi (pewarnaan Gram)}

Dari 7 isolat yang diuji teridentifikasi 5 isolat sebagai Coccus Gram negatif dan 2 isolat sebagai Bacilli Gram negatif.

\section{Uji fisiologi (uji motilitas)}

Hasil pengujian pada ketujuh isolat didapatkan lima isolat menunjukkan hasil yang positif yaitu bakteri menunjukkan pertumbuhan menyebar baik disekitar tempat penusukan sampai permukaan media. 
Sedangkan dua isolat (S.U 40 B.K dan S.U 20 B.K) menunjukkan hasil negatif dimana pertumbuhan bakteri tidak menyebar dan hanya bertumbuh lurus didaerah penusukan.

\section{Uji biokimia}

\section{Uji indol}

Hasil yang didapatkan menunjukkan bahwa hanya satu isolat (S.K 20 B.K) yang memberikan hasil negatif. Keenam isolat lainnya menunjukkan hasil yang positif, yaitu terbentuk cincin berwarna merah di permukaan media setelah diberikan 5 tetes reagen kovac's dan didiamkan selama 10 menit. Hal ini menunjukkan bahwa bakteri mengandung enzim tripfanase yang merupakan katalis pengurai indol yang terkandung dalam asam amino triptofan.

\section{$\mathrm{Uji} \mathrm{H}_{2} \mathrm{~S}$}

Hasil uji $\mathrm{H}_{2} \mathrm{~S}$ didapatkan hanya satu isolat (S.K 40 B.P) yang menunjukkan hasil positif dimana terbentuk endapan berwarna hitam pada dasar (butt) dari media.

\section{Uji fermentasi karbohidrat}

Uji fermentasi karbohidrat dilakukan bersama - sama dengan uji pembentukan $\mathrm{H}_{2} \mathrm{~S}$ pada media TSIA (triple sugar iron agar). Hasil yang didapatkan menunjukkan ketujuh isolat mengalami perubahan warna dari merah menjadi kuning pada bagian dasar (butt) dan bagian miring (slant). Sehingga dapat disimpulkan bahwa isolat ini dapat memfermentasikan laktosa dan sukrosa, namun tidak dapat memfermentasikan glukosa. Ketujuh isolat juga menghasilkan gas $\mathrm{CO}_{2}$ sebagai sisa proses fermentasi dimana pada ketujuh isolat didapatkan adanya pembentukkan gas pada dasar media.

\section{Uji Katalase}

Uji katalase yang dilakukan menunjukkan hasil yang positif pada semua isolat yang ada. Terbentuknya gelombang gas pada semua isolat ini menunjukkan bakteri memiliki enzim katalase yang berfungsi menguraikan $\mathrm{H}_{2} \mathrm{O}_{2}$ yang ditambahkan ke koloni bakteri menjadi $\mathrm{H}_{2} \mathrm{O}$ dan $\mathrm{O}_{2}$.

\section{Uji sitrat}

Hasil uji sitrat pada ketujuh isolat menunjukkan hasil yang positif dimana terjadi perubahan warna media dari hijau menjadi biru. Hal ini menunjukkan bahwa bakteri mampu menggunakan sitrat sebagai sumber karbon dan energi.

\section{Uji lysine dekarboksilase}

Hasil uji lysine dekarboksilase menunjukkan hasil positif pada enam isolat yang ada, sedangkan hanya terdapat satu isolat (S.K 40 B.P) yang menunjukkan hasil negatif. Hasil positif terdapat pada media yang berwarna lembayung (ungu), sementara hasil negatif pada media berwarna kuning.

Hasil dari identifikasi bakteri yang meliputi uji morfologi, fisiologi dan biokimia yang diperoleh selanjutnya akan digabungkan dan digunakan untuk menentukkan bakteri yang terkandung pada setiap isolat yang ada. Penentuan bakteri dilakukan dengan membandingkan hasil uji yang diperoleh dengan Data yang terdapat dalam buku Bergey's Manual Determinative of bacteriology. ${ }^{14}$

\section{BAHASAN}

\section{Isolasi bakteri resisten merkuri}

Hasil uji resistensi bakteri dengan menggunakan media $\mathrm{NB}$ yang berisi $\mathrm{HgCl}_{2}$ dengan konsentrasi 10 ppm, 20 ppm dan 40 ppm dan Fenil Merkuri 5 ppm, 10 ppm dan 20 ppm menunjukkan masing-masing media ditemukan pertumbuhan koloni bakteri. Dengan kata lain bakteri dapat tumbuh pada konsentrasi tertinggi $\mathrm{HgCl}_{2} 40 \mathrm{ppm}$ dan Fenil Merkuri 20 ppm. Selanjutnya diambil 6 isolat dari 18 isolat yang ada untuk ditumbuhkan pada cawan petri dan diamati bentuk koloni, permukaan dan warna dari setiap isolat. Pada isolat S.F 40 didapatkan bentuk yang berbeda yaitu bulat bergerigi sehingga dari uji ini didapatkan 7 isolat yang akan diambil dan dipindahkan pada media gores dan agar miring sehingga didapatkan bakteri murni untuk uji selanjutnya. 


\section{Identifikasi bakteri}

\section{Pewarnaan Gram}

Bakteri berukuran sangat kecil dan tipis sehingga sukar dilihat struktur tubuhnya walaupun dengan bantuan mikroskop. Untuk melihat morfologi bakteri secara lebih jelas dikembangkan teknik pewarnaan bakteri. Prinsip pewarnaan bakteri adalah pertukaran antara ion zat warna dengan ion protoplasma sel.

Terdapat dua kelompok zat pewarna bakteri, yaitu: (1) bersifat asam, berupa anion dan umum digunakan dalam bentuk garam natrium. (2) bersifat alkali, berupa kation dan umum digunakan dalam bentuk klorida. Selain zat warna diperlukan zat tambahan yang berfungsi untuk mengendapkan hasil reaksi zat warna dengan kmponen dinding sel bakteri. Zat tersebut dikenal dengan istilah Pematek yang akan melekatkan zat warna pada plasma sel.

Pengamatan morfologi bakteri hasil pewarnaan dilakukan dibawah pengamatan mikroskop. Berdasarkan Pewarnaan Gram, bakteri diklasifikasikan ke dalam dua kelompok besar yaitu : Bakteri Gram Positif dan Gram Negatif. Perbedaan utama di antara keduanya adalah struktur dan komposisi dinding selnya. Bakteri Gram Positif mampu mempertahankan zat warna utama dalam pewarnaan Gram, yaitu Gentian Violet, sehingga nampak warna ungu saat pengamatan dikarenakan dinding sel kelompok bakteri ini tersusun oleh sebagian besar Peptodoglikan, yang mampu mengikat zat warna dan tidak rusak saat dicuci dengan alkohol. Sementara itu, Bakteri Gram Negatif memiliki komposisi dinding sel yang sebagian besar tersusun dari lapisan lipid, sehingga pada saat pewarnaan kurang dapat mempertahankan zat warna utama terutama saat dicuci dengan alkohol (lipid rusak saat dicuci dengan alkohol), akibatnya kelompok bakteri ini memberikan kenampakan warna merah (warna dari zat warna kedua: safranin atau air fuchsin) diakhir kegiatan pewarnaan Gram.

Pada hasil identifikasi bakteri didapatkan Staphylococcus dan Bacillus merupakan Gram negatif pada uji morfologi (pewarnaan Gram), hal ini dikarenakan adanya kesalahan pada tahap dekolorisasi yang mengakibatkan $C V$-iodine lepas dari sel. Pemberian ethanol berlebihan akan menyebabkan overdecolorization sehingga sel Gram positif tampak seperti Gram negatif.

\section{Uji motilitas}

Motilitas bakteri adalah suatu gerakan bakteri yang disebabkan adanya gerakan aktif dan gerakan pasif. Gerak aktif adalah gerakan bakteri yang disebabkan karena bakteri memiliki flagel. Gerak pasif disebabkan karena faktor dari luar (gerak brown). Gerak brown adalah suatu gerakan yang dapat menggetarkan partikel-partikel secara acak atau terarah karena terus menerus terkenan pukulan molekul-molekul kecil tak terlihat yang terdapat dalam cairan.

Motilitas dapat diamati dengan baik pada biakan yang masih baru. Pada biakan yang sudah lama, bakteri sudah mati, sehingga sukar untuk mendapat sel yang motil, selain itu produksi asam dan produk yang bersifat racun dapat menyebabkan hilangnya motalitas sel bakteri pada biakan. Hampir semua sel bakteri spiral dan sebagian dari bakteri basil bersifat motil, sedangkan bakteri yang berbentuk kokus bersifat immotil.

\section{Uji indol}

Prinsip dari uji ini adalah menentukan kemampuan mikroorganisme untuk menghasilkan indol dari triptofan. Asam amino triptofan merupakan komponen asam amino yang lazim terdapat pada protein, sehingga asam amino ini dengan mudah dapat digunakan oleh mikroorganisme akibat penguraian protein. Bakteri tertentu seperti E. coli mampu menggunakan triptofan sebagai sumber karbon. E. coli menghasilkan enzim triptofanase yang mengkatalisasikan penguraian gugus indol dari triptofan. Dalam media biakan, indol menumpuk sebagai produk buangan, sedangkan bagian lainnya dari molekul triptofan dapat digunakan untuk memenuhi kebutuhan zat hara mikroorganisme. 
Pembentukan indol dari triptofan oleh mikroorganisme dapat diketahui dengan menumbuhknnya dalam media biakan yang kaya dengan triptofan. Triptofan biasaya diberikan dalam bentuk tripton, suatu polipeptida yang kaya dengan residu triptofan. Penumpukan indol dalam media biakan dapat diketahui dengan penambahan berbagai reagen. Reagen bereaksi dengan indol dan menghasilkan senyawa yang tidak larut dalam air dan berwarna merah pada permukaan media.

\section{Uji $\mathrm{H}_{2} \mathrm{~S}$ dan Fermentasi Karbohidrat}

Pengujian ini menggunakan medium TSIA (Triple Sugar Iron Agar). $\mathrm{H}_{2} \mathrm{~S}$ di produksi oleh beberapa jenis mikroorganisme melalui pemecahan asam amino yang mengandung unsur belerang (S) seperti lisin dan metionin. $\mathrm{H}_{2} \mathrm{~S}$ dapat juga diproduksi melalui reduksi senyawasenyawa belerang anorganik, misalnya: tisulfat, sulfit atau sulfat. Adanya $\mathrm{H}_{2} \mathrm{~S}$ diamati dengan menambahkan garam-garam logam berat ke dalam medium. Dikatakan positf apabila $\mathrm{H}_{2} \mathrm{~S}$ bereaksi dengan senyawa-senyawa ini ditandai dengan terbentuknya logam sulfit yang berwarna hitam. Dan dikatakan negatif apabila tidak terbentuk logam sulfit yang berwarna hitam karena bakteri yang berada dalam medium tersebut tidak dapat menghidrolisis logamlogam berat yang terkandung dalam medium.

Pada percobaan ini, reaksi yang dapat timbul adalah:

a. Kuning pada butt (dasar) dan merah pada slant (permukaan miring), menunjukkan adanya fermentasi glukosa.

b. Kuning pada butt dan slant, menunjukkan adanya fermentasi laktosa dan/atau sukrosa.

c. Pembentukan gas, yang ditandai dengan pembentukan ruang udara dibawah medium sehingga medium terangkat keatas.

d. Pembentukan gas $\left(\mathrm{H}_{2} \mathrm{~S}\right)$, terlihat dari pembentukan warna hitam pada medium.

e. Merah pada butt dan slant, menunjukkan tidak adanya fermentasi gula dan pembentukan gas atau pembentukan $\mathrm{H}_{2} \mathrm{~S}$.

\section{Uji katalase}

Beberapa bakteri yang memiliki flavoprotein dapat mereduksi $\mathrm{O}_{2}$ dengan menghasilkan hidrogen peroksida $\left(\mathrm{H}_{2} \mathrm{O}_{2}\right)$ atau superoksida $\left(\mathrm{O}_{2}^{-}\right)$. Kedua bahan ini merupakan bahan yang toksik dan menghancurkan komponen sel dengan sangat cepat. Bakteri harus dapat mempertahankan diri dengan memproduksi $\mathrm{O}_{2}$ atau akan terbunuh.

Beberapa bakteri dapat memproduksi enzim yang dapat mengkatalisis superoksida yaitu peroksida dismutase, dan juga katalase atau peroksidase yang dapat mendekstruksi hidrogen peroksida. Katalase adalah enzim yang mengkatalisasikan penguraian hydrogen peroksida $\left(\mathrm{H}_{2} \mathrm{O}_{2}\right)$ menjadi air dan $\mathrm{O}_{2}$. Hidrogen peroksida terbentuk sewaktu metabolime aerob, sehingga meikroorganisme yang tumbuh dalam lingkungan aerob dapat menguraikan zat toksik tersebut. Penentuan adanya katalase ini terlihat dari pembentukan gelembung udara disekitar koloni setelah ditambahkan larutan $\mathrm{H}_{2} \mathrm{O}_{2} 3 \%$.

\section{Uji sitrat}

Uji sitrat digunakan untuk melihat kemampuan mikroorganisme menggunakan sitrat sebagai satu-satunya sumber karbon dan energi. Bila mikroba mampu menggunakan sitrat, maka asam akan dihilangkan dari medium biakan, sehingga menyebabkan peningkatan $\mathrm{pH}$ dan mengubah warna medium dari hijau menjadi biru.

\section{Uji lysine dekarboksilase}

Dekarboksilase merupakan proses penguraian gugus karboksil dari suatu molekul organik. Proses dekarboksilase asam amino lazimnya menghasilkan $\mathrm{CO}_{2}$; molekul yang telah didekarboksilasikan digunakan dalam sintesis berbagai komponen. Proses dekarboksilasi asam amino seringkali juga digunakan untuk menetralisasikan lingkungan asam. Sewaktu prosesfermentasi mikroorganisme sering menghasilkan hasil sampingan yang bersifat asam yang dapat menghambat pertumbuhan mikroorganisme. Enzim dekarbiksilase mengenyahkan gugus asam dari gugus asam 
amino dan menghasilkan amina yang menyebabkan media pertumbuhan bersifat basa. Proses dekarboksilasi lisin dapat diketahui dengan menumbuhkan mikroorganisme dalam biakan yang mengandung lisin. Karbohidrat yang dapat difermentasikan (glukosa) dan indikator $\mathrm{pH}$ untuk melihat perubahan $\mathrm{pH}$. Asam yang dihasilkan dari proses fermentasi glukosa akan menurunkan $\mathrm{pH}$ media biakan dan menyebabkan perubahan warna dari indikator $\mathrm{pH}$ dari ungu menjadi kuning. Dalam suasana asam ini proses dekarboksilasi lisin dapat berlangsung sehingga terjadi pembentukan amin yang menetralisasikan suasana asam media pertumbuhan mikroorganisme. Proses netralisasi asam ini terlihat sebagai perubahan warna dari kuning menjadi ungu seperti sedia kala; perubahan warna menjadi ungu ini menunjukkan bahwa lisin mengalami dekarboksilasi.

Identifikasi bakteri pada penelitian ini dengan menggunakan buku Bergey's Manual Determinative of bacteriology di dapatkan 3 genus bakteri yaitu E. Coli, Staphylococcus dan Bacillus sp.Hal ini menunjukkan bahwa terdapat berbagai genus bakteri resisten merkuri yang ada di dalam tubuh manusia.

\section{SIMPULAN}

1. Terdapat bakteri resisten merkuri pada urine, feses dan karang gigi yang diambil dari individu di Kecamatan Malalayang. Ada 3 genus bakteri yang ditemukan yaitu E. Coli, Staphylococcus dan Bacillus sp.

2. Tingkat resistensi bakteri terhadap merkuri yang tertinggi pada peneltian ini yang dilakukan pada konsentrasi $\mathrm{HgCl}_{2}$ 10 ppm, 20 ppm dan 40 ppm yaitu pada konsentrasi 40 ppm. Pada Fenil Merkuri dengan konsentrasi 5 ppm, 10 ppm dan 20 ppm yaitu pada konsentrasi 20 ppm.

\section{DAFTAR PUSTAKA}

1. Hersutanto Begi. Makna Negara Kepulauan. Jakarta: Badan Koordinasi Keamanan Laut; 2009. h.37.
2. Suseno Heny, Hudiyono Sumi, Budiawan, Wisnubroto. Bioakumulasi Merkuria Anorganik dan Metil Merkuri Oleh Oreochromis mossambicus: Pengaruh Konsentrasi Merkuri Anorganik dan Metil Merkuri Dalam Air. Jurnal Teknologi Pengelolaan Limbah. 2010;13:49.

3. Fatimawali, Badaruddin Fatmawaty, Yusuf Irawan. Isolasi dan Identifikasi Bakteri Resisten Merkuri dari Muara Sungai Sario yang Dapat Digunakan Untuk Detoksifikasi Limbah Merkuri. Jurnal Ilmiah Sains. 2011;11:282-288.

4. Bruce Lourie. Mercury in The Environment: a Primer. Canada: Pollution Probe; 2003. p.12-28.

5. U.S EPA. Characterization of Human Health and Wildlife Risks from Mercury Exposure in the United Stated. Volume VII. Washington, DC: Environmental Protection Agency, Office of Science and Technology, Office of Water; 1997.

6. Ruzickova K. Halting The Child Brain Drain. Czech Republic: HCWH Europe;2006. p. 831.

7. McKew Deborah. Global Mercury Hotspots : New Evidence Reveals Mercury Contamination Regularly Exceeds Health Advisory Levels in Humans and Fish Worldwide. Biodiversity Research Institute and IPEN;2013. p. 1-20.

8. Haley Boyd. Mercury Toxicity : Genetic Susceptibility and Synergistic Effects. Medical Veritas. 2005;2:535.

9. Hyman Mark. The Impact of Mercury on Human Health and The Environment. Alternative Therapies. 2004;10:71.

10. McKew Deborah. Mercury in The Global Environment : Patterns of Global Seafood Mercury Concentration and Their Relationship With Human Health. Biodiversity Research Institute. Gorham, Maine: BRI Science Communications Series;2012.p. 2.

11. Mikrobiologi Dasar. Purwokerto: Fakultas Biologi Universitas Jenderal Soedirman; 2008.

12. Widiyanti Atik, Shovitri Maya, Dwiannita Nengah. Isolasi dan karakterisasi bakteri resisten merkuri di hilir Kali Mas Surabaya. Surabaya: Institut Teknologi Sepuluh Nopember; 2011.

13. Pratiwi A. Penampisan bakteri resisten terhadap merkuri sebagai alternatif agen bioremediasi pada pencemaran tanah 
540 Jurnal e-Biomedik (eBM), Volume 2, Nomor 2, Juli 2014, hlm. 532-540

pertambangan [Skripsi]. Bogor: Institut

Pertanian Bogor;2012.

14. Breed Se, EGD. Murray and Hitchens AP.
Bergey's

Manual

Determinative

Bacteriology. Baltimore: The William and Company;

1948.

Tabel 3. Hasil Uji Morfologi, Uji Fisiologi dan Uji Biokimia

\begin{tabular}{|c|c|c|c|c|c|c|c|c|c|c|c|c|c|}
\hline \multirow{3}{*}{$\begin{array}{l}\text { Kode } \\
\text { isolat }\end{array}$} & \multirow{2}{*}{\multicolumn{2}{|c|}{$\begin{array}{c}\text { Uji morfologi } \\
\text { Pewarnaan gram } \\
\end{array}$}} & \multirow{3}{*}{$\begin{array}{c}\text { Uji } \\
\text { fisiologi } \\
\text { motil }\end{array}$} & \multirow[b]{3}{*}{ Katalase } & \multirow[b]{3}{*}{ indol } & \multicolumn{4}{|c|}{ Uji biokimia } & \multirow[b]{3}{*}{$\mathbf{H}_{2} \mathrm{~S}$} & \multirow[b]{3}{*}{ Citrat } & \multirow[b]{3}{*}{ Lysin } & \multirow{3}{*}{$\begin{array}{c}\text { Hasil } \\
\text { identifikasi } \\
\text { Genus Bakteri }\end{array}$} \\
\hline & & & & & & \multicolumn{4}{|c|}{ Uji fermentasi karbohidrat } & & & & \\
\hline & Bentuk & $\begin{array}{c}\text { Bakteri } \\
\text { gram }\end{array}$ & & & & glukosa & laktosa & sukrosa & Gas & & & & \\
\hline s.f 40b.p & Coccus & Negatif & + & + & + & - & + & + & + & - & + & + & E.coli \\
\hline s.f 40b.p & Coccus & Negatif & + & + & + & - & + & + & + & - & + & + & E.coli \\
\hline s.u40b.k & Coccus & Negatif & - & + & + & - & + & + & + & - & + & + & E.coli \\
\hline s.k40b.p & Coccus & Negatif & + & + & + & - & + & + & + & - & + & - & $\begin{array}{c}\text { Staphylococcus } \\
\text { sp } \\
\end{array}$ \\
\hline s.f 20b.p & Coccus & Negatif & + & + & + & - & + & + & + & - & + & + & E.coli \\
\hline s.u 20b.k & Bacilli & Negatif & - & + & + & - & + & + & + & + & + & + & Bacillus sp. \\
\hline s.k20b.k & Bacilli & Negatif & + & + & - & - & + & + & + & - & + & + & Bacillus sp. \\
\hline
\end{tabular}

Bergey's Manual Determinative of bacteriology 